\title{
Manoel Correia de Andrade (1922-2007)
}

Fui surpreendido, no dia 22 de junho, ao ler o SBPC-Pernambuco Notícias, com a informação de que neste mesmo dia falecera o geógrafo e historiador Manoel Correia de Andrade. Mais do que uma notícia fúnebre - era minha memória que corria para os anos 60, quando assistia às aulas do emérito professor Manoel Correia no Colégio Estadual de Pernambuco, hoje (re)denominado de Ginásio Pernambucano. Professor da Universidade Federal de Pernambuco, Mestre Manoel era também membro da Academia Pernambucana de Letras e, por algum tempo, prestou brilhantes serviços a FUNDAJ (Fundação Joaquim Nabuco). No final da década de 90 também prestou assessoria à Universidade Estadual da Paraíba.

Filho de senhor de engenho, nasceu em 1922 e sua mãe descendia do Ministro João Alfredo Correia de Oliveira que redigiu a Lei Áurea, sobre quem o neto publicaria João Alfredo: o estadista da abolição. Manoel Correia rompeu com a tradição e entrou no Partido Comunista em 1942, mas nele passou apenas alguns meses. Participou das manifestações contra o Estado Novo, sendo preso e processado, mas anistiado em 1944. Em 1945 formou-se em Direito pela Universidade Federal de Pernambuco, sempre advogando causas trabalhistas de sindicatos.Veio, dois anos mais tarde, a se licenciar em Geografia e História pela Universidade Católica de Pernambuco.

Começou a ensinar em 1952, no ensino médio. Ao desenvolver esta atividade publicou seu primeiro livro, destinado ao antigo curso Ginasial em São Paulo: Geografia do Brasil. Tornou-se um dos assessores do primeiro Governo Arraes e, em 1963, sob os auspícios de Caio Prado 
Júnior, que lhe prefaciou a obra, Manoel lançou, em São Paulo, o seu clássico e polêmico A terra e o homem no Nordeste. Este livro tido como subversivo pela ditadura (chegou a ser apreendido após o golpe de 1964), e não-científico por geógrafos, que não o consideraram obra acadêmica, foi, posteriormente, editada até mesmo nos Estados Unidos. Em meio à polêmica suscitada pela publicação de A terra e o homem no Nordeste, fez, ainda, cursos de Estudo Técnico do Meio Natural, na Universidade de Paris (1965). Era um homem cosmopolita, pois visitou vários países como Israel, Japão, Argentina; deu palestras e conferências no Peru, no México, na Colômbia, na França e nos Estados Unidos.

Na UFPE, coordenou os Mestrados em Economia e em Geografia, de onde se aposentou em 1983, passando a diretor do Centro de Estudos de História Brasileira (CEHIBRA) da Fundação Joaquim Nabuco, no Recife, cargo que ocupou até 2003. Recebeu o título de Doutor Honoris Causa por diversas universidades UFRN, UFAL, UFES e Universidade Católica de Pernambuco.

Além de ter sido seu aluno, conheci a obra do Mestre em meu de História, com seus livros Movimentos nativistas em Pernambuco: Setembrizada e Novembrada, publicados no Recife, em 1971. Provavelmente o Mestre se enquadraria aqui no que o francês Dosse fala: o tempo da historiografia, uma sutil maneira de ver os movimentos populares do passado com olhos do presente. Freqüentador da antiga livraria Livro 7, lá às vezes conversávamos sobre política e universidade, assim, quase que de raspão, ele fazendo suas compras e dando dois dedos de prosa com seu ex-aluno e agora colega na profissão. Comentávamos os efeitos da ditadura nos cargos da UFPE, onde dois grupos se digladiavam: de um lado, o grupo de Manoel e demais perseguidos; do outro, o grupo com apoio da Reitoria de então, que contava com um ou outro esquerdista e com o pessoal da Adesg. Minha simpatia ia para o grupo de Manoel, porque lá estavam os esquerdistas, os injustiçados c os cassados, como o Historiador Amaro Quintas. Confabulavase na Livro 7.

Como geógrafo, teve participação social c política no primeiro governo Arraes, mas, homem discreto, não praticava a panfletagem e sim, pesquisa consciente, como se seguisse os passos do outro injustiçado, Josué de Castro, de Geografia da Fome.Trabalhou com uma excelente equipe de geógrafos pernambucanos, como Gilberto Osório e Rachel 
Caldas, produzindo ensaios inclusive sobre o rio Paraíba e o Mamanguape, e com economistas como Tânia Bacelar, formando todo um estofo intelectual e científico de esquerda, dentro daquilo que se chamou de desenvolvimentismo sudenista.

Voltamos a nos encontrar na década de 90 como sócios fundadores da Associação Brasileira de Pesquisadores em História Econômica (ABPHE), na qual o mestre deixa grande lacuna. Sua atuação não se limitava apenas a escrever - mais de 100 livros, traduzidos em várias línguas, além de mais de duas centenas de artigos publicados. O brilhante e incansável pesquisador atuava ainda como conselheiro e assessor.

Josemir Camilo de Melo*

* Doutor em História pela Universidade Federal de Pernambuco com a tese "Modernização e mudanças: O trem inglês nos canaviais do Nordeste (1852-1902)". Professor Aposentado e Visitante da Universidade Federal da Paraíba, e-mail: jcdmelo@uol.com.br 